\title{
UPAYA MENINGKATKAN HASIL BELAJAR MATEMATIKA MATERI OPERASI PERKALIAN MELALUI PROBLEM BASED LEARNING
}

\author{
Ida Kurnia, Sukardi \\ SD Negeri Cisoka \\ email korespondensi: idakurnia37@yahoo.com
}

\begin{abstract}
Penelitian ini dilatarbelakangi oleh hasil belajar siswa masih rendah. Ini terlihat dari nilai hasil ulangan siswa kelas IV di SD Negeri Cisoka yaitu 12 siswa atau 57,14\% yang memperoleh nilai dibawah KKM (Kriteria Ketuntasan Minimal) dan 9 siswa atau $42,86 \%$ yang mencapai KKM. Penelitian ini bertujuan untuk meningkatkan hasil belajar siswa pada pembelajaran Matematika melalui Penelitian Tindakan Kelas. Subjek dalam penelitian ini yaitu kelas IV SD Negeri Cisoka dengan jumlah 21 siswa terdiri dari 11 siswa laki-laki dan 10 siswa perempuan. Hasil penelitian menunjukan perolehan hasil belajar siswa pada data nilai ulangan harian semester 1 rata-ratanya 60,95 dengan persentase ketuntasan belajar $42,86 \%$ meningkat pada siklus I rata-rata 69,87 dengan persentase ketuntasan belajar 61,90\% dan meningkat pada siklus II rata-rata 80,64 dengan persentase ketuntasan belajar sebesar $80,95 \%$.
\end{abstract}

Kata Kunci: Problem Based Learning, Hasil Belajar Siswa 


\section{PENDAHULUAN}

Mata pelajaran Matematika bertujuan agar peserta didik memiliki kemampuan diantaranya memahami konsep Matematika menggunakan penalaran pada pola dan sifat, memecahkan masalah, mengkomunikasikan gagasan dengan simbol dan memiliki sikap menghargai kegunaan Matematika dalam kehidupan. Menurut Purwanto (2014: 54) hasil belajar adalah perubahan perilaku yang terjadi setelah mengikuti proses belajar mengajar sesuai dengan tujuan pendidikan.

Observasi awal pada siswa kelas IV di SD Negeri Cisoka untuk mata pelajaran Matematika pencapaian hasil belajar yang berkaitan dengan domain penerapan C3: menghitung. Dilihat dari hasil kemampuan kognitif setiap evaluasi akhir dari Standar Kompetensi atau Kompetensi Dasar pembelajaran Matematika hanya $42,86 \%$ siswa yang mendapatkan nilai diatas atau sama dengan KKM yang telah ditentukan dari banyaknya siswa 21 siswa, siswa yang mencapai KKM hanya terdapat 9 siswa dan 12 siswa yang belum mencapai KKM..

Materi perkalian bilangan merupakan salah satu materi dalam pembelajaran Matematika yang dianggap sulit bagi siswa sekolah dasar. Pembelajaran Matematika materi perkalian bilangan harus diberikan secara bermakna kepada siswa Sekolah Dasar. Selama ini, siswa melakukan perkalian bilangan hanya tahu bilangannya saja tanpa tahu maknanya. Pembelajaran Matematika yang abstrak tersebut mudah dilupakan siswa, sehingga guru harus mengulang kembali apa yang sudah dipelajari siswa sebelumnya. Melihat situasi tersebut dibutuhkan model pembelajaran yang inovatif dan tepat untuk merangsang kemampuan bernalar siswa, karena pada dasarnya belajar Matematika secara keseluruhan merupakan belajar memecahkan masalah.

Problem Based Learning atau Pembelajaran Berbasis Masalah merupakan model pembelajaran memiliki karakteristik yang khas, yaitu menggunakan masalah dunia nyata sebagai konteks belajar bagi siswa. Marra dan H. Jonassen (2014: 221) Problem-based learning (PBL) is an instructional method that drives all learning via solving an authentic problem.

Wardani (2007:27) mengatakan, "Model pembelajaran berbasis masalah dapat menyajikan masalah autentik dan bermakna sehingga siswa dapat melakukan penyelidikan dan menemukan sendiri"

Berdasarkan hasl tersebut Problem Based Learning (PBL) di anggap mampu meningkatkan hasil belajar siswa, dikarnakan menyajikan permasalahanpermasalahan yang autentik.

\section{KAJIAN LITERATUR DAN PEGEMBANGAN HIPOTESIS}

a. Operasi Hitung Perkalian Sekolah Dasar

Peneliti mengambil mata pelajaran Matematika di semester I dengan materi perkalian bilangan yaitu membahas tentang algoritma perkalian/perkalian bersusun seperti:

(1) Menghitung bilangan satu angka dengan bilangan dua angka dan tiga angka

(2) Menghitung bilangan 10 secara berulang dan bilangan kelipatan 10

(3) Menghitung bilangan dua angka dengan bilangan dua angka dan tiga angka.

Pada prinsipnya, perkalian sama dengan penjumlahan secara berulang. Oleh karena itu, kemampuan prasyarat yang harus dimiliki siswa sebelum mempelajari perkalian adalah penguasaan penjumlahan. Perkalian termasuk topik yang sulit untuk 
dipahami sebagian siswa. Adapun Standar Kompetensi dan Kompetensi Dasar yang sudah ditetapkan dalam kurikulum, yaitu sebagai berikut :

Tabel 1. SK dan KD

\begin{tabular}{|l|l|}
\hline $\begin{array}{l}\text { Standar } \\
\text { Kompetensi }\end{array}$ & $\begin{array}{l}\text { Kompetensi } \\
\text { Dasar }\end{array}$ \\
\hline Bilangan & 1.3.Melakukan \\
1.Memahami dan & operasiperkalian \\
menggunakan \\
danpembagian \\
sifat-sifat operasi \\
hitung bilangan \\
dalam pemecahan \\
masalah
\end{tabular}

b. Problem Based Learning (PBL)

Problem Based Learning (PBL) pertama kali di perkenalkan dalam dunia medis oleh Howard S. Barrows dan M.D. Robyn M. Tamblyn, B.Se.N. Barows and Tamblyn (1980: 1) Learning from problems is a condition of human existence. Barows dengan konsisten menggunakan $P B L$ sebagai pendekatan berkembang ke tingakat sekolah untuk digunakan sebagai pendekatan pembelajaran. Sehingga berkembang pengertian Problem Based Learning (PBL) adalah suatu kegiatan pembelajaran yang berpusat pada masalah. Masalah merupakan kesenjangan antar harapan dan kenyataan. Christina De Simone (2014: 18) PBL is a learner-centered pedagogical approach that affordslearners (including prospective and certified teachers) opportunities to engage in goaldirected inquiry.

Dalam pengembangan pembelajaran Problem Based Learning $(P B L)$, masalah didefinisikan sebagai proses atau upaya untuk menyelesaikan tugas atau situasi yang benar-benar baru dengan meggunakan aturan-aturan yang sudah diketahui sebelumnya. Problem Based Learning $(P B L)$ merupakan rangkaian aktivitas pembelajaran yang menekankan kepada proses penyelesaian masalah yang dihadapi secara ilmiah.

\section{METODE PENELITIAN}

Penelitian dilakukan diawali dengan observasi awal dan penyusunan proposal pada bulan Januari-Maret agar penelitian lebih relevan dan terarah. Tahap jadwal penelitian mulai dari tahap observasi awal, tahap penyusunan proposal, kemudiantahap persiapan penelitian seperti penyusunan instrumen berupa Rencana Pelaksanaan Pembelajaran, tes, dan pengamatan, dan lain-lain. Diakhiri dengan pengiriman laporan hasil penelitian.Tahap penelitian tindakan kelas, terdiri dari prasiklus, dua siklus yang masing-masing siklus terdiri dari satu tindakan jadi seluruhnya 2 tindakan disesuaikan dengan model desain Kemmis dan Mc. Taggart. Penelitian dilaksanakan di Kelas IV SD Negeri Cisoka Kecamatan Cikijing Kabupaten Majalengka tahun pelajaran 2016/2017.

Menurut McNiff (Kusumah, 2012:8) PTK sebagai bentuk penelitian reflektif yang dilakukan oleh guru sendiri yang hasilnya dapat dimanfaatkan sebagai alat untuk pengembangan keahlian mengajar. Penelitian Tindakan Kelas pada umumnya berupa perangkatperangkat atau untaian-untaian dengan satu perangkat terdiri dari empat komponen:

1) Perencanaan (plan).

2) Melaksanakan tindakan (act),

3) Melaksanakan pengamatan (observe),

4) Mengadakan refleksi / analisis (reflection)

\section{HASIL DAN PEMBAHASAN}

a. Penerapan Model Problem Based Learning

Pada Mata Pelajaran Matematika di Kelas IV IV di SD Negeri Cisoka Berdasarkan hasil penelitian yang telah 
dilakukan, penerapan model Problem Based Learning sebagai model dalam proses pembelajaran dapat dilihat dari lembar observasi guru dikelas. Persentase hasil observasi guru siklus I $95,24 \%$ dan siklus II $100,00 \%$ mengalami peningkatan sebesar 4,76 dengan kategori sangat tinggi. Penelitian ini apabila dilihat dari model pembelajarannya ini sama hal yang dilaksanakan peneliti terdahulu oleh Pratiwi (2013) menyebutkan bahwa hasil observasi guru dengan penerapan model mendapat kategori A/Istimewa. Adapun hasil observasi guru pada tiap siklus diperoleh data sebagai berikut:

Tabel 2. Hasil Observasi Guru

\begin{tabular}{|l|l|l|l|}
\hline No & Indikator & Siklus 1 & Siklus 2 \\
\hline 1 & $\begin{array}{l}\text { Kemampuan } \\
\text { guru } \\
\text { membuka } \\
\text { pelajaran }\end{array}$ & 3 & 3 \\
\hline 2 & $\begin{array}{l}\text { Sikap guru } \\
\text { dalam proses } \\
\text { pembelajaran }\end{array}$ & 3 & 3 \\
\hline 3 & $\begin{array}{l}\text { Kemampuan } \\
\text { penguasaan } \\
\text { materi } \\
\text { pembelajaran }\end{array}$ & 2 & 3 \\
\hline 4 & $\begin{array}{l}\text { Penggunaan } \\
\text { media } \\
\text { pembelajaran }\end{array}$ & 2 & 2 \\
\hline 5 & $\begin{array}{l}\text { Implementasi } \\
\text { langkah- } \\
\text { langkahpembe } \\
\text { lajaran }\end{array}$ & 3 & 3 \\
\hline 6 & $\begin{array}{l}\text { Evaluasi } \\
\text { Pembelajaran }\end{array}$ & 2 & 3 \\
\hline 7 & $\begin{array}{l}\text { Kemampuan } \\
\text { menutup } \\
\text { pembelajaran }\end{array}$ & 3 & 3 \\
\hline Total & 18 & 20 \\
\hline Persentase (\%) & $85,71 \%$ & $95,23 \%$ \\
\hline
\end{tabular}

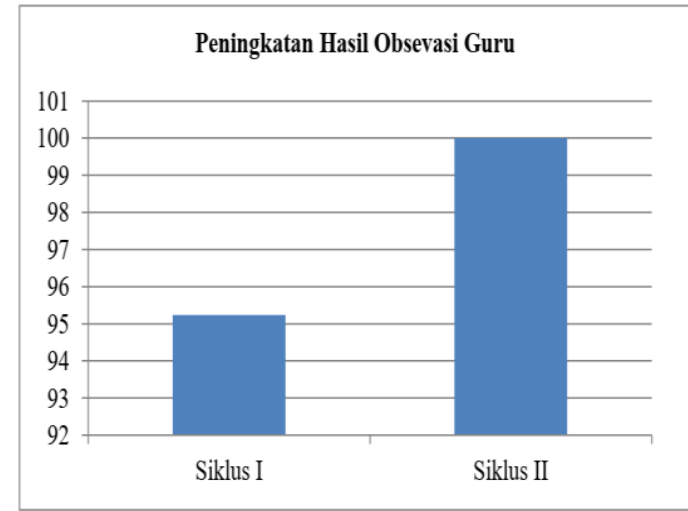

Gambar 1. Peningkatan hasil obervasi guru

b. Hasil Belajar Siswa pada Mata

Pelajaran Matematika di Kelas IV di SD Negeri Cisoka

Berdasarkan hasil penelitian yang telah dilakukan, penerapan model Problem Based Learning sebagai model dalam proses pembelajaran dapat dilihat dari hasil tes dan hasil observasi kegiatan siswa dikelas. Persentase hasil belajar siswa pada pra siklus sebesar $42,86 \%$, siklus I sebesar 61,90\%, dan siklus II 80,95\%. Hasil tersebut mengalami peningkatan 38,09\% dengan persentase terakhir $80,95 \%$ yang sudah dinyatakan mencapai indikator keberhasilan yaitu sebesar 75\%. Ratarata hasil belajar siswa pada pra siklus 60,95, siklus I 69,87 dan siklus II 80,64. Hasil tersebut mengalami peningkatan 19,69 dengan rata-rata hasil belajar terakhir 80,64 yang sudah mencapai KKM dan mencapai kategori sangat tinggi. Hasil belajar siswa tersebut merupakan hasil penjumlahan nilai dari ranah kognitif, afektif dan psikomotor hal ini sependapat dengan Benyamin S.Bloom (Arifin, 2014: 21) menyampaikan bahwa tiga ranah hasil belajar siswa, yaitu ranah kognitif, afektif dan psikomotor. 


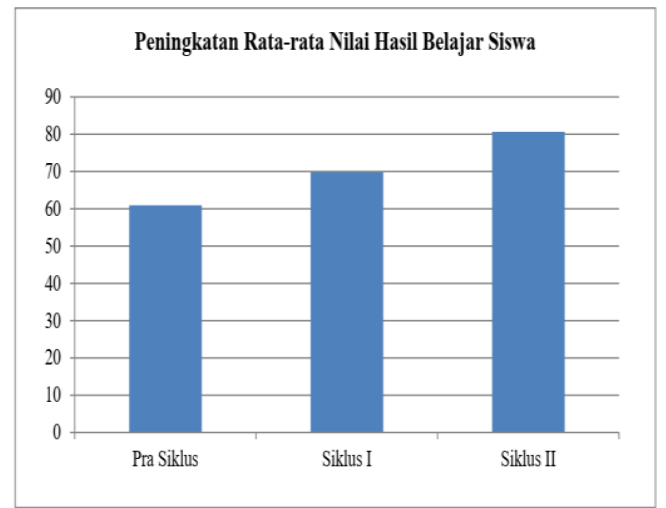

Gambar 2. Peningkatan rata-rata nilai hasil belajar siswa

Rata-rata hasil belajar siswa pada pra siklus 60,95, siklus I 69,87 dan siklus II 80,64. Hasil tersebut mengalami peningkatan 19,69 dengan rata-rata hasil belajar terakhir 80,64. Peningkatan persentase ketuntasan belajar dapat dilihat pada grafik berikut:

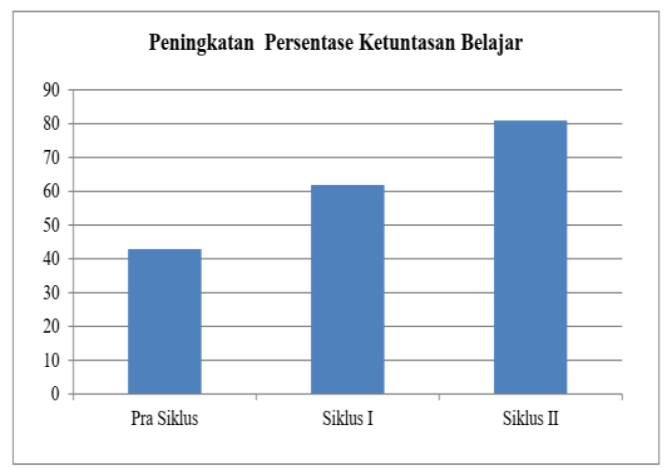

Gambar 3. Peningkatan persentase ketuntasan belajar

Persentase hasil belajar siswa pada pra siklus sebesar 42,86\%, siklus I sebesar $61,90 \%$, dan siklus II 80,95\%. Hasil tersebut mengalami peningkatan 38,09\% dengan persentase terakhir $80,95 \%$.

\section{c. Implementasi Problem Based Learning (PBL)}

Berdasarkan hasil dan pembahasan di atas, menunjukan bahwa kegiatan guru dan kegiatan siswa dalam pembelajaran mengalami peningkatan dan indikator keberhasilan telah tercapai. Hal ini ditunjukan bahwa adanya peningkatan hasil belajar siswa kelas IV di SD Negeri Cisoka terhadap Matematika melalui penerapan model Problem Based Learning (PBL). Dibuktikan dengan persentase hasil belajar siswa pada pra siklus sebesar $42,86 \%$, siklus I sebesar 61,90\%, dan siklus II 80,95\%. Hasil tersebut mengalami peningkatan $38,09 \%$ dengan persentase terakhir $80,95 \%$ yang telah mencapai indikator keberhasilan.

Penelitian mengenai penerapan model Problem Based Learning terhadap hasil belajar siswa Matematika siswa kelas IV di SD Negeri Cisoka, yang terdiri dari 21 siswa serta dilaksanakan dalam 2 siklus dan masing-masing siklus terdiri dari 1 tindakan. Hasil ke-2 siklus tersebut kemudian diolah dan dianalisis menurut prosedur yang telah dibahas pada bab sebelumnya. Berdasarkan hasil penelitian yang dipaparkan pada sub bab sebelumnya, diketahui bahwa penerapan model Problem Based Learning pada proses pembelajaran Matematika materi perkalian bilangan di kelas IV SDN Batujaya I mendapat predikat yang sangat tinggi. Hal ini terlihat hasil observasi kegiatan guru di depan kelas mendapat Persentase Nilai $=100 \%$ yang termasuk kategori sangat tinggi. Bila dilihat dari hasil belajar siswa, hasil belajar siswa pada kondisi awal sebelum dilaksanakan penelitian, nilai rata-rata kelasnya hanya 60,95 dan persentase ketuntasannya 42,86\%. Hasil penerapan model Problem Based Learning pada proses pembelajaran 
matematika bisa dilihat dari nilai hasil belajar siswa siklus I dan siklus II. Pada siklus I, nilai rata-rata $=69,87$ atau meningkat 8,92 dari kondisi awal dan nilai rata-rata hasil belajar siswa pada siklus II $=80,63$ atau meningkat 19,68 dari kondisi awal. Berdasarkan nilai tersebut, hasil belajar siswa yang menerapkan model Problem Based Learning lebih baik dibandingkan dengan sebelumnya. Data tes berupa nilai hasil belajar siswa yang dianalisis untuk menentukan ketuntasan dimana apabila siswa yang mendapat nilai $>69$ maka dinyatakan tuntas, sedangkan apabila nilainya $<69$ maka dinyatakan belum tuntas $(\mathrm{KKM}=69)$. Bila $>75 \%$ siswa yang tuntas, maka kelas tersebut dikatakan tuntas belajarnya. Pada kondisi awal persentase ketuntasan hanya $42,86 \%$, sedangkan pada siklus I persentase ketuntasannya $61,90 \%$ atau naik 19,04\% dari kondisi awal. Apabila dilihat dari siklus II, persentase ketuntasan sebesar $80,95 \%$ atau naik 38,09\% dari kondisi awal. Pada akhir siklus II diperoleh persentase ketuntasan sebesar 80,95\% maka kelas tersebut dikatakan tuntas dalam pembelajarannya, sehingga tidak perlu dilakukan tindakan pada siklus selanjutnya. Keseluruhan pelaksanaan pembelajaran Matematika dengan menerapkan model Problem Based Learning, peneliti menemukan kelebihan dan kekurangan dari model Problem Based Learning, yaitu: 1) Kelebihan model Problem Based Learning

(a) Model Problem Based Learning mengembangkan kemampuan berpikir kritis siswa dalam memecahkan suatu masalah (b). Meningkatkan belajar berkolaborasi dan komunikatif dalam memecahkan suatu masalah. (c). Meningkatkan kreativitas guru dalam proses pembelajaran (d). Membuat siswa terbiasa menghadapi masalah terutama terhadap kehidupan nyata, (e). Menumbuhkan motivasi, keberanian, rasa percaya diri, dan semangat siswa dalam proses pembelajaran.

2) Kekurangan model Problem Based Learning: (a). Pembelajaran menerapkan model Problem Based Learning memerlukan kreativitas yang tinggi karena banyak yang harus dipersiapkan oleh guru dalam menyajikan kegiatan pembelajaran. (b). Diperlukan biaya dan tenaga yang tidak sedikit untuk menerapkan model Problem Based Learning.

\section{KESIMPULAN}

Pembelajaran Matematika dengan menerapkan model Problem Based Learning pada proses pembelajaran Matematika sub bab Perkalian Bilangan di kelas IV SD Negeri Cisoka mendapat predikat sangat tinggi. Hal itu terlihat dari hasil observasi kegiatan guru di depan kelas mendapat Persentase Siklus $\mathrm{I}=95,24 \%$ dan Siklus II $=100 \%$ yang termasuk kategori sangat tinggi. Hasil penerapan model Problem Based Learning pada proses pembelajaran bisa dilihat dari nilai rata-rata hasil belajar siswa pada siklus I dan siklus II. Hasil belajar pada kondisi awal dari hasil Ulangan Harian, nilai rata-rata kelasnya hanya 60,95. Pada siklus I, nilai rata-rata hasil belajar siswa $=69,87$ atau naik 8,92 dari kondisi awal dan pada siklus II nilai rata-rata hasil belajar siswa $=80,63$ atau naik 19,68 dari kondisi awal. Berdasarkan nilai tersebut, hasil belajar siswa yang 
menerapkan model Problem Based Learning lebih baik dibandingkan dengan sebelumnya. Pembelajaran Matematika dengan menerapkanmodel Problem Based Learning terbukti dapat meningkatkan hasil belajar siswa kelas IV SD Negeri Cisoka. Hal itu dapat dilihat dari persentase peningkatan hasil belajar siswa kelas IV SD Negeri Cisoka. Persentase hasil belajar siswa pada kondisi awal hanya 42,86\%, kemudian pada siklus I sebesar $61,90 \%$ atau naik $19,04 \%$ dari kondisi awal dan pada akhir siklus II sebesar $80,95 \%$ atau naik 38,09\% dari kondisi awal. Pada akhir siklus II persentase ketuntasan belajar sebesar 80,95\%, persentase tersebut sudah mencapai indikator keberhasilan sebesar 75\% maka kelas IV SD Negeri Cisoka dinyatakan tuntas dengan kategori sangat tinggi.

\section{REFERENSI}

Barrows, Howard S., \& Tamblyn, M.D. Robyn. (1980). Problem-Based Learning An Approach to Medical Education. Springer Publishing Company. New York

Kusumah, et. All. (2012). Mengenal Penelitian Tindakan Kelas. Jakarta. Indeks.

Marra, R., Jonassen, D. H., Palmer, B., \& Luft, S. (2014). Why problembased learning works: Theoretical foun-dations. Journal on Excellence in College Teaching, 25(3\&4), 221-238

Purwanto. (2014). Evaluasi Hasil Belajar. Yogyakarta: Pustaka Belajar

Simone, Christina De. (2014). ProblemBased Learning in Teacher Education: Trajectories of Change. International Journal of Humanities and Social Science. Vol. 4,No. 12; October 2014
Wardhani, Sri dkk. 2010. Pembelajaran Kemampuan Pemecahan Masalah Matematika di SD. Yogyakarta: PPPPTK. 